Research Article

\title{
Flexible Temporary Shield in Soft and Sensitive Clay: 3D FE Modelling of Experimental Field Test
}

\author{
Miah Alam, ${ }^{1}$ Omar Chaallal, ${ }^{1}$ and Bertrand Galy $\mathbb{D}^{2}$ \\ ${ }^{1}$ Department of Construction Engineering, Université de Québec, École de Technologie Supérieure, Montreal, QC, Canada H3C 1 K3 \\ ${ }^{2}$ Department of Research, Québec Occupational Health and Safety Research Institute (IRSST), 505 de Maisonneuve Blvd., West, \\ Montreal, Canada H3A 3C2
}

Correspondence should be addressed to Bertrand Galy; bertrand.galy@irsst.qc.ca

Received 16 October 2020; Revised 25 January 2021; Accepted 8 February 2021; Published 25 February 2021

Academic Editor: Jean-Michel Bergheau

Copyright (c) 2021 Miah Alam et al. This is an open access article distributed under the Creative Commons Attribution License, which permits unrestricted use, distribution, and reproduction in any medium, provided the original work is properly cited.

A finite-element (FE) numerical study using PLAXIS-3D software was carried out to reproduce and validate a full-scale experimental in situ test and to investigate the earth pressure on a flexible temporary trench box shield in soft and sensitive clay soil. The excavation trench model was $6 \mathrm{~m}(20 \mathrm{ft})$ deep and was considered as nonlinear and anisotropic clay. A $45 \mathrm{kPa}(0.94 \mathrm{ksf})$ surface overload on top of the soil near the trench box was also simulated to produce a maximum load case on the flexible wall of the shield. Both Mohr-Coulomb (MC) and hardening soil (HS) constitutive soil models were considered for FE analysis. Different values of the modulus reduction factor (MRF) and the coefficient of earth pressure at rest $\left(K_{0}\right)$ were considered to validate the model. For a specific shear strength profile, FE analysis with a linear elastoplastic soil model showed relatively small differences in soil pressure with the field test results along the depth of the trench. Results were also compared with the predictions of well-established analytical formulae.

\section{Introduction}

Over the past decades, various analytical studies have been carried out to improve our understanding of the behavior of braced excavation protection systems [1]. As a protection system, the trench box shield is different from other braced systems because, instead of shoring up or otherwise supporting the trench face, it primarily aims to protect workers from cave-ins or similar incidents. Shields shall not be subjected to loads exceeding those that the system can withstand [2]. The earth pressure distribution on a shield depends on the type of soil, the shoring, and the method of installation. Generally, no satisfactory consensual theoretical solutions are available to estimate soil pressure for this type of supporting structure with partitions facing land pressures in sensitive clay [3]. Many researchers have suggested theoretical solutions to estimate earth pressure on a flexible temporary support ([4-6]). Consequently, for an excavation shield, the Canadian Foundation Engineering Manual [4] recommends the use of pressure envelopes from empirical formulae.
Our understanding of the behavior of excavations and trenches with flexible retaining walls has evolved significantly in recent years with the help of numerical FE and analytical methods. Using FE analyses, Goldberg-Zoino, and Associates, Inc [5] found that under a given set of soil conditions, the higher the wall rigidity, the greater was the apparent earth pressure. A study by Hashash and Whittle [7] on shoring excavations in clay has shown that the evolution of lateral thrust on a retaining structure (or wall) is a complex function of the flexibility of the retaining structure and the magnitude of shear deformations at depth. Their analyses also revealed the development of an arching effect in the ground in contact with the shoring. Karlsrud and Andresen [1] concluded that the development of earth pressure on supporting structures set up in sensitive clays is a complex function that depends on the flexibility of the support, the anisotropy property, the thickness of the clay layer in the trench bottom, and deformations in the clay layer. Lam [8] showed that a mobilized strength design database can be used to investigate the relationship between structural response ratio and soil- 


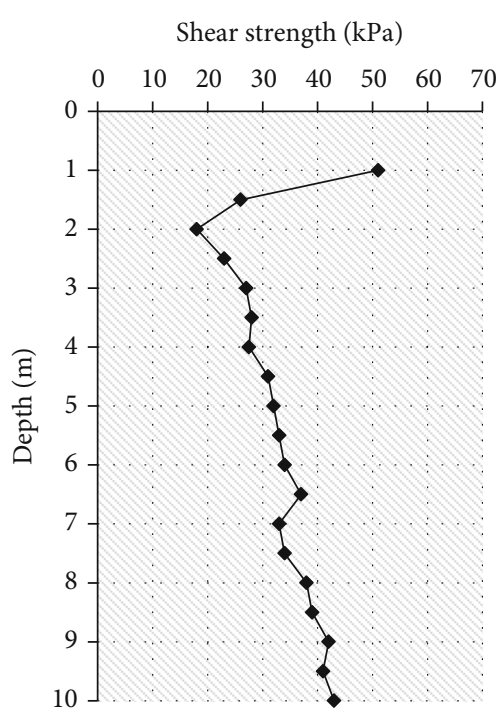

(a)

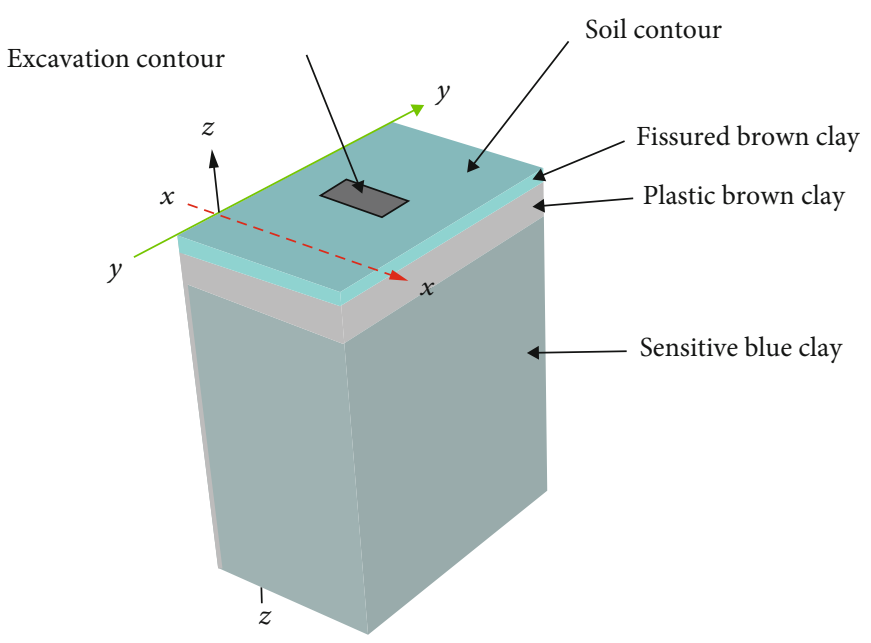

(b)

FIgURE 1: Geometric profile and excavation contour in PLAXIS-3D simulation of trench: (a) experimental values of soil shear strength at Louiseville site (data adapted from Laval University); (b) PLAXIS-3D model profile for Louiseville soil (number of soil elements: 23,221; MC soil model).

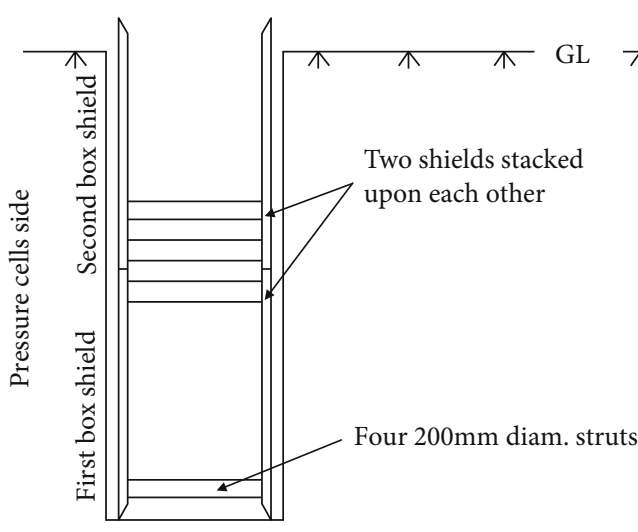

Elevation side 1

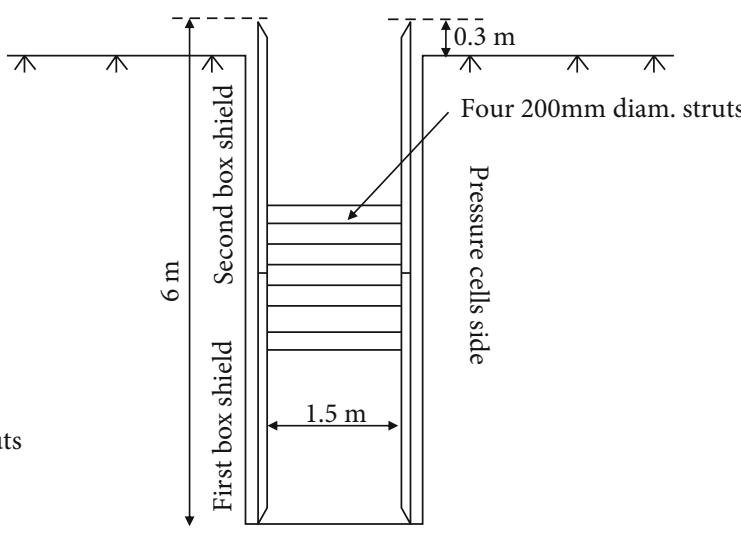

Elevation side 2

FIGURE 2: Elevation views of trench and shield.

structure stiffness ratio and to capture the range of wall stiffnesses between sheet piles and thick diaphragm walls. Bryson and Zapata-Medina [9] FE work clearly showed the influence of horizontal and vertical strut spacing, wall stiffness, and relative stiffness ratio on lateral wall deformation in an excavation support system (ESS) in three types of clays. However, their work focused on $12 \mathrm{~m}$ deep trenches, and a research gap has been observed for trench box shoring at shallower depths of less than $6 \mathrm{~m}$ and for soil-structure interaction (SSI) considerations [10]. It may be worth noting that trenches of less than $6 \mathrm{~m}$ are very common in practice and particularly in soft and sensitive clay. Therefore, there is a need to study the interaction between the soft and sensitive soil mass and the support, the flexibility in the development of lateral loads, and the movement of structural elements for shallow trench box shoring.
This paper presents the details of an FE model and of simulations using the PLAXIS-3D software [11] to simulate a flexible temporary shield in soft and sensitive clay, with particular emphasis on the Mohr-Coulomb (MC) versus hardening soil (HS) constitutive laws used for the soil layers, the structure and the soil-structure interaction, the sequence of excavation, and the installation of the temporary flexible shield walls. The impact of the shear strength of a specific type of soft and sensitive clay on earth pressures will be studied. The results will also be compared to theoretical and experimental field test results.

\section{Finite-Element Analyses}

Numerical analyses of the performance of an excavation support system for most recent deep excavation case histories 
TABLE 1: Geometric and mechanical properties of box shield protection used for FE simulation in PLAXIS-3D.

\begin{tabular}{|c|c|c|c|}
\hline Parameter/properties & PLAXIS-3D nomenclature (unit) & Strut (spreader tube) & Plate \\
\hline Material type & Type & Elastic & Elastic, isotropic \\
\hline \multirow{2}{*}{ Young's modulus } & $E_{1}\left(\mathrm{kN} / \mathrm{m}^{2}\right)$ & $2 \times 10^{8}$ & $2 \times 10^{8}$ \\
\hline & $E_{2}\left(\mathrm{kN} / \mathrm{m}^{2}\right)$ & & $2 \times 10^{8}$ \\
\hline Unit weight & $\gamma\left(\mathrm{kN} / \mathrm{m}^{3}\right)$ & 78.50 & 13.67 \\
\hline Cross-section area & $A\left(\mathrm{~m}^{2}\right)$ & 0.01 & \\
\hline \multirow{2}{*}{ Moment of inertia } & $I_{2} x x\left(\mathrm{~m}^{4}\right)$ & $4.41 \times 10^{-5}$ & \\
\hline & $I_{3} y y\left(\mathrm{~m}^{4}\right)$ & $4.41 \times 10^{-5}$ & \\
\hline Thickness & $d(\mathrm{~m})$ & & 0.10 \\
\hline Poisson's ratio & $v_{12}$ & & 0.30 \\
\hline \multirow{3}{*}{ Shear Modulus } & $G_{12}\left(\mathrm{kN} / \mathrm{m}^{2}\right)$ & & $8 \times 10^{7}$ \\
\hline & $G_{13}\left(\mathrm{kN} / \mathrm{m}^{2}\right)$ & & $8 \times 10^{7}$ \\
\hline & $G_{23}\left(\mathrm{kN} / \mathrm{m}^{2}\right)$ & & $8 \times 10^{7}$ \\
\hline \multirow{4}{*}{ From $200 \mathrm{~mm}$ strut SCH80 chart } & Outer diameter strut, $d_{\mathrm{o}}(\mathrm{mm})$ & 219 (8.63 in) & \\
\hline & Inner diameter strut, $d_{\mathrm{i}}(\mathrm{mm})$ & 194 (7.63 in) & \\
\hline & Area of strut $\left(\mathrm{m}^{2}\right)$ & $8.24 \times 10^{-3}$ & \\
\hline & $I_{y y}$ or $I_{x x}$ for strut $\left(\mathrm{m}^{4}\right)$ & $4.41 \times 10^{-5}$ & \\
\hline \multirow{4}{*}{ One shield geometry } & Length $(\mathrm{m})$ & $3.0(10 \mathrm{ft})$ & \\
\hline & Height (m) & $3.0(10 \mathrm{ft})$ & \\
\hline & Plate thickness (mm) & 100 (4 in) & \\
\hline & Horizontal distance between struts (m) & 2.6416 (104 in) & \\
\hline
\end{tabular}

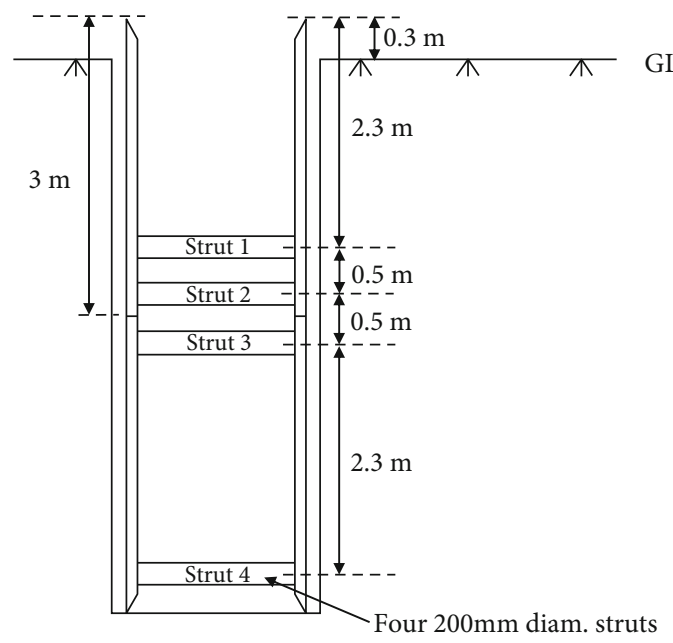

Elevation side 1

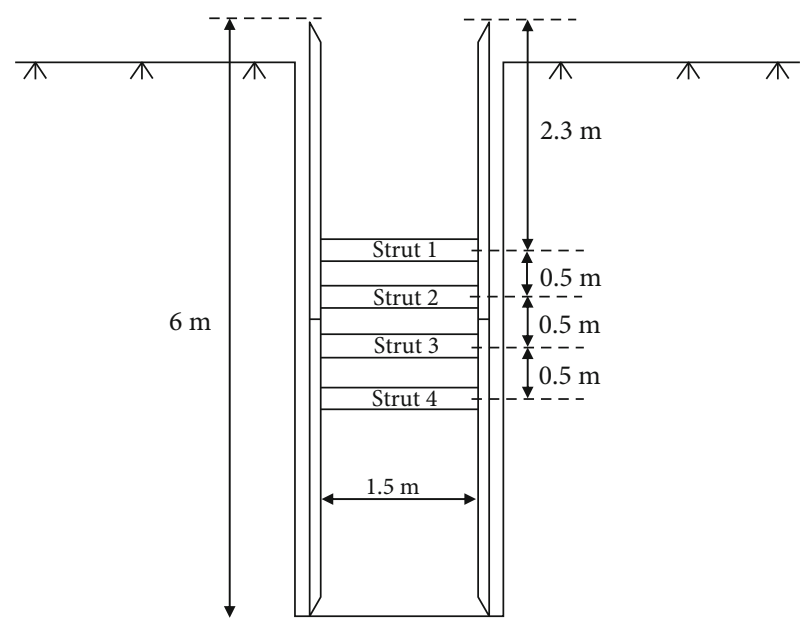

Elevation side 2

FIgURE 3: Strut spacing and locations in the two assembled box shields (stacked upon each other).

have required three-dimensional FE analyses [12]. In addition, Ou et al. [13] have shown that the complex soilstructure interactions of excavation support systems and excavation-induced ground movements are threedimensional (3D) in nature. To perform this 3D FE analysis (FEA) and obtain a better understanding of these complex soil-structure interactions, the PLAXIS-3D software was used. Analysis output (soil pressure) was com- pared with field test results obtained for Louiseville, Quebec, Canada [14].

\section{Parameters for FE}

To simulate the trench with the excavation protection shield, three types of parameters were used in PLAXIS-3D: (i) soil model parameters for the excavation and surrounding soil, 


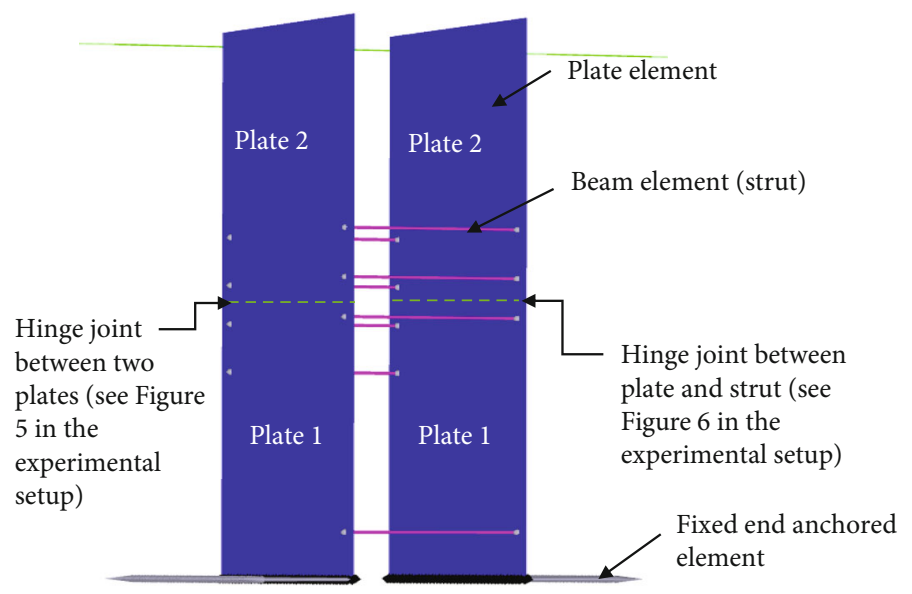

FIGURE 4: Structural simulation of the two assembled box shield (stacked upon each other) protection in PLAXIS-3D (number of structural elements: 1,050; MC soil model).

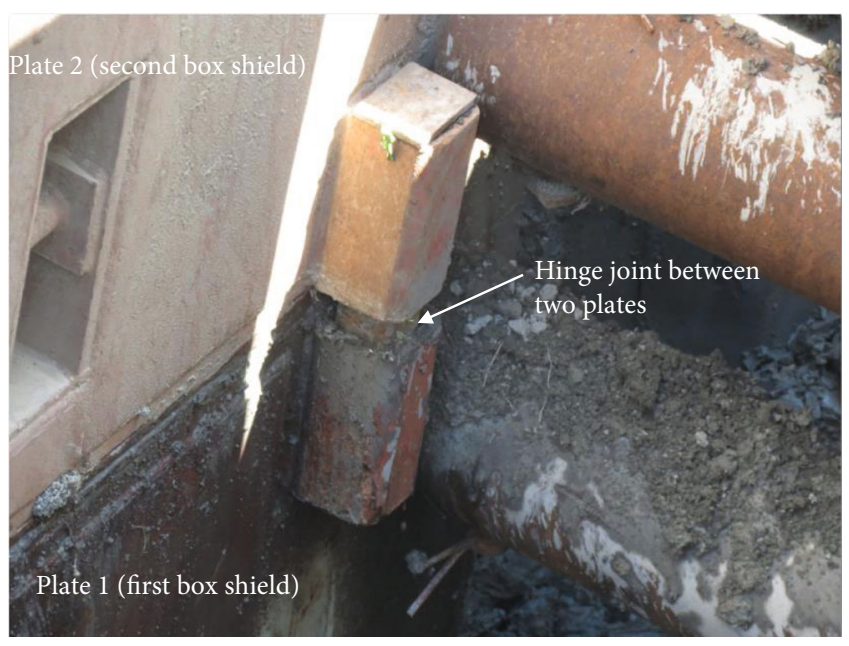

Figure 5: Experimental hinge joint between two plate walls of assembled box shields (stacked upon each other).

including all the layers; (ii) structural model parameters for the box shield protection; and (iii) interface parameters.

3.1. Soil Modelling. The boundaries of the finite-element models were extended beyond the settlement zone of influence induced by the excavation, as determined in accordance with procedures recommended by Hsieh and $\mathrm{Ou}$ [15]. To simulate the trench, a soil model geometry such as soil contour $[7.5 \mathrm{~m}(25 \mathrm{ft}) \times 12 \mathrm{~m}(40 \mathrm{ft}) \times 15 \mathrm{~m}(50 \mathrm{ft})]$ was assumed, which was more than twice the excavation contour $[3 \mathrm{~m}(10$ $\mathrm{ft}) \times 1.5 \mathrm{~m}(5 \mathrm{ft}) \times 6 \mathrm{~m}(20 \mathrm{ft})]$. The Louiseville soil layers were modelled using three depths and properties: (i) $0 \mathrm{~m}$ to $0.6 \mathrm{~m}$ (2ft) of depth of soil as fissured brown clay, (ii) $0.6 \mathrm{~m}$ (2ft) to $2 \mathrm{~m}(6.56 \mathrm{ft})$ depth of soil as plastic brown clay, and (iii) $2 \mathrm{~m}(6.56 \mathrm{ft})$ to $15 \mathrm{~m}(50 \mathrm{ft})$ depth of soil as sensitive blue clay in accordance with the stratigraphic profile of the Louiseville soil. Soil properties, especially strength, required careful attention because they are a key factor in the overall performance of the excavation support system (ESS) [16]. Supporting this statement, the in situ value of soil shear strength in Louiseville shown in Figure 1(a) was used in this FEA. The soil contour with the trench model is shown in Figure 1(b).

3.2. Structural Modelling. Bryson and Zapata-Medina [9] indicated that the stiffness of an excavation support system (ESS) is a complex function of the flexural rigidity of the wall element, the structural stiffness of the support elements, the type of connections between the wall and the supports, and the vertical and horizontal spacing of the support system. Therefore, the two trench steel shields "stacked upon each other" to cover the total depth $(6 \mathrm{~m}(20 \mathrm{ft}))$ of excavation were simulated according to the geometrical dimensions shown in Figure 2 and Table 1. The positions and locations of the struts used for simulation are shown in Figure 3.

Other parameters such as plate and strut mechanical properties are presented in Table 1. The Young's modulus $(E)$, shear modulus $(G)$, and Poisson's ratio $(v)$ of $4.76 \mathrm{~mm}$ (3/16 in) thick A-572 grade 50 steel plate were assumed. Plate unit weight $(\gamma)$ was calculated from the total weight of the shield, and an equivalent $100 \mathrm{~mm}$ (4 in) thick sandwich plate was considered as per PLAXIS-3D input. For the struts (or spreader tube), Young's modulus $(E)$ and unit weight $(\gamma)$ were taken from the $200 \mathrm{~mm}$ strut SCH80 chart. Crosssectional area $(A)$ and moment of inertia $(I)$ were calculated from the original strut diameter. The vertical positions of the struts were made different on both sides to allow the excavator to access the soil to be excavated between the two walls of the shield.

In the PLAXIS-3D simulation, the box shield steel builtin plate walls (sandwich plate as per PLAXIS-3D) are modelled as "plate elements" and the struts as "beam elements." Four-cornered "hinge joints" were used between the two box shields (stacked upon each other) to represent the experimental setup shown in Figures 4 and 5. Similarly, the joints between the struts and the plates were simulated as "hinge joints" and were representative of the experimental setup illustrated in Figures 4 and 6. Note that the bottom end part of the shield (around $300 \mathrm{~mm}$ ) was embedded into the soil and that the total gravity load of the upper steel box was 


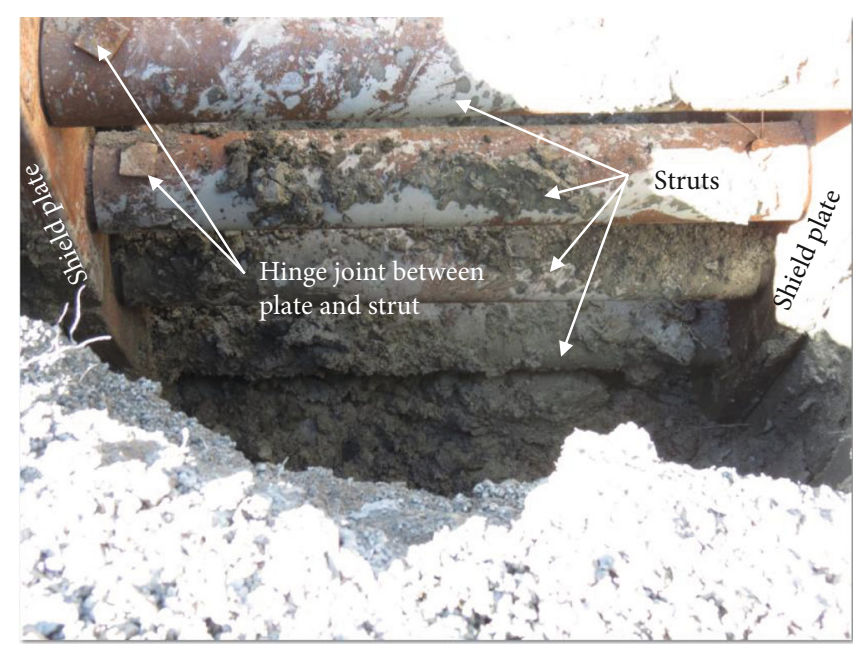

Figure 6: Experimental hinge joint between plate and strut of box shield.

TAble 2: Properties for Louiseville soil and Mohr-Coulomb material model parameters used for FE modelling.

\begin{tabular}{|c|c|c|c|c|}
\hline Parameter/properties & PLAXIS nomenclature (unit) & Fissured brown clay & Plastic brown clay & Sensitive blue clay \\
\hline Depth of layer & $\mathrm{m}$ & $0.0-0.6$ & $0.6-2$ & $2-15$ \\
\hline Material model & Model & $\mathrm{MC}$ & $\mathrm{MC}$ & $\mathrm{MC}$ \\
\hline Drainage type & Type & Drained & Undrained $B$ & Undrained $B$ \\
\hline Unit wt. above phreatic level & $\gamma_{\text {unsat }}\left(\mathrm{kN} / \mathrm{m}^{3}\right)$ & 16 & 16 & 16 \\
\hline Unit wt. below phreatic level & $\gamma_{\text {sat }}\left(\mathrm{kN} / \mathrm{m}^{3}\right)$ & 17 & 17 & 17 \\
\hline Young's modulus & $E\left(\mathrm{kN} / \mathrm{m}^{2}\right)$ & See Table 3 & See Table 3 & See Table 3 \\
\hline Cohesion & $C_{\mathrm{ref}}^{\prime}\left(\mathrm{kN} / \mathrm{m}^{2}\right)$ & 5 & 5 & 5 \\
\hline Frictional angle & $\varnothing\left(^{\circ}(\right.$ degree $\left.)\right)$ & 28 & 28 & 28 \\
\hline Dilatancy angle & $\Psi\left({ }^{\circ}(\right.$ degree $\left.)\right)$ & 0 & 0 & 0 \\
\hline Poisson's ratio & $v_{\mathrm{ur}}^{\prime}$ & 0.3 & 0.3 & 0.3 \\
\hline Interface strength reduction factor & $R_{\text {inter }}$ & 0.66 & 0.5 & 0.5 \\
\hline Initial $K_{0}$ determination & & 0.53 & 0.53 & 0.53 \\
\hline Soil type & & & & Very fine \\
\hline$<2 \mathrm{~m} \mu$ & $\%$ & 10 & 10 & 74 \\
\hline $2 \mathrm{~m} \mu-50 \mathrm{~m} \mu$ & $\%$ & 13 & 13 & 11 \\
\hline
\end{tabular}

pushing the lower box shield into the ground during installation of the experiment. Therefore, the bottom part (around $300 \mathrm{~mm}$ ) of the lower box acted more likely as a "fixed end support" in the experiment and was represented by a "fixed end anchored element," as illustrated in Figure 4.

To analyze the nonlinear stress-strain behavior of the soil model in the trench and the soil surrounding the excavation, two constitutive material models, (a) Mohr-Coulomb (MC) and (b) hardening soil (HS), were used in this study.

3.3. Generating the Mohr-Coulomb (MC) Model. The MC model is a simple and widely used linear elastic perfectly plastic model. The linear elastic part of the Mohr-Coulomb model is based on Hooke's law of isotropic elasticity, and the perfectly plastic part is based on the MC failure criterion [11]. For a first approximation to see the behavior in general, the MC model was chosen. Table 2 shows the soil parameters for the Mohr-Coulomb (MC) model used for finite-element modelling of the Louiseville sensitive clay. The soil stiffness moduli $(E)$ at different depths were calculated from the shear strength $\left(C_{u}\right)$ in the Louiseville soil test results using the equation proposed by Peck [17]:

$$
E=600 * C_{u}
$$

Table 3 presents the average values of $E\left(E_{\mathrm{avg}}\right)$ for PLAXIS-3D input. In the soil model, the stress-strain relationship depends on the soil skeleton. The soil response is influenced by pore pressure. This water-skeleton interaction was considered as a plastic calculation using a PLAXIS-3D drainage-type parameter. For the $0.6 \mathrm{~m}$ layer of fissured brown clay, "drained" behavior was assumed, and therefore, in this layer, no excess pore pressure was generated, and full drainage was assumed due to the low rate of loading. On the 
TABLE 3: Calculation of $E$ for different layers of plastic brown and sensitive blue clay.

\begin{tabular}{|c|c|c|c|}
\hline Depth (m) & $C_{u}(\mathrm{kPa})$ & $E(\mathrm{kPa})$ & $E_{\text {avg. }}(\mathrm{kPa})$ \\
\hline 0 & 0 & 0 & 0 \\
\hline 0.6 & 25 & 15,000 & 15,000 \\
\hline 1 & 51 & 30,600 & \multirow{2}{*}{20,400} \\
\hline 1.5 & 26 & 15,600 & \\
\hline 2 & 18 & 10,800 & \multirow{2}{*}{13,600} \\
\hline 2.5 & 23 & 13,800 & \\
\hline 3 & 27 & 16,200 & \multirow{2}{*}{16,500} \\
\hline 3.5 & 28 & 16,800 & \\
\hline 4 & 27.5 & 16,500 & \multirow{2}{*}{18,100} \\
\hline 4.5 & 31 & 18,600 & \\
\hline 5 & 32 & 19,200 & \multirow{2}{*}{19,800} \\
\hline 5.5 & 33 & 19,800 & \\
\hline 6 & 34 & 20,400 & \multirow{2}{*}{20,800} \\
\hline 6.5 & 37 & 22,200 & \\
\hline 7 & 33 & 19,800 & \multirow{2}{*}{21,000} \\
\hline 7.5 & 34 & 20,400 & \\
\hline 8 & 38 & 22,800 & \multirow{2}{*}{23,800} \\
\hline 8.5 & 39 & 23,400 & \\
\hline 9 & 42 & 25,200 & \multirow{2}{*}{25,200} \\
\hline 9.5 & 41 & 24,600 & \\
\hline 10 & 43 & 25,800 & 25,800 \\
\hline 11 & 43 & 25,800 & 25,800 \\
\hline 12 & 45 & 27,000 & 27,000 \\
\hline 13 & 48 & 28,800 & 28,800 \\
\hline 14 & 44 & 26,400 & 26,400 \\
\hline
\end{tabular}

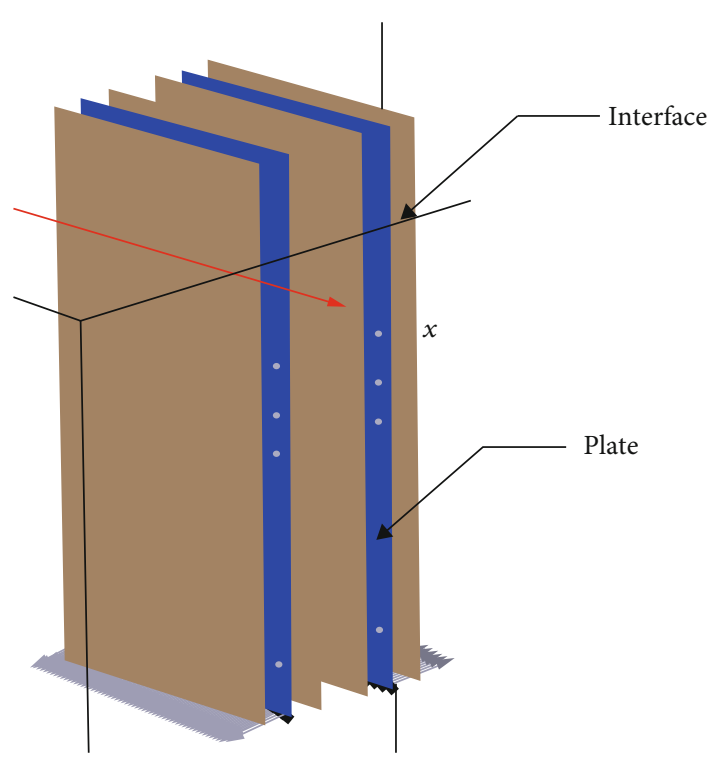

Figure 7: Interfaces in the PLAXIS-3D model.

other hand, in the saturated soil layer, pore water cannot freely flow through the soil skeleton (due to low permeability) [11].
TABLE 4: Seasonal water head variation readings (data adapted from Laval University).

\begin{tabular}{lc}
\hline Time frame & Water head from top of soil (m) \\
\hline 14-May-18 & 0.92 \\
8-Jun-18 & 1.2 \\
22-Jun-18 & 1.8 \\
22-Jul-18 & 2 \\
3-Aug-18 & 2.5 \\
\hline
\end{tabular}

This phenomenon is described by PLAXIS-3D as an undrained behavior for brown clay and sensitive blue clay. To make sure that the soil skeleton is much more compressible than the pore water, the effective Poisson's ratio should be less than 0.35 for the undrained $(B)$ condition [11]. For practical reasons, the undrained $(B)$ option was chosen because this method allows the Louiseville shear strengths $\left(S_{u}\right)$ to be used as input parameters in PLAXIS-3D. This does not hold true in the undrained $(A)$ condition, where shear strength $\left(S_{u}\right)$ is rather a consequence of the model, not an input parameter. On the other hand, the undrained $(C)$ condition was not considered because, although the shear strength parameter $\left(S_{u}\right)$ is an input parameter, it cannot provide a prediction of pore pressure. The undrained $(C)$ method is not suitable for consolidation analysis [11].

3.4. Interface Model. Interfaces were added as a joint element to the plates for proper modelling of soil-structure interaction. They represent a thin zone of intensely shearing material at the contact between a plate and the surrounding soil. Positive and negative interfaces were added (local $z$-direction) on either side of a plate surface (Figure 7). The interface properties included material mode, permeability condition, and virtual thickness factor. The interaction between the steel plate wall and the soil was expressed by a suitable strength reduction factor $\left(R_{\text {inter }}\right)$. This factor relates the interface strength (wall friction and adhesion) to the soil strength (friction angle and cohesion). Recommended values for $R_{\text {inter }}$ are as follows: $2 / 3$ for fissured brown clay and $<2 / 3$ for plastic brown and sensitive blue soft clay [11] (Table 2). The interface was assigned an imaginary dimension called the virtual thickness. In the MC and HS models, the virtual thickness of the interface element varied with mesh type and ranged between $103 \times 10^{-3} \mathrm{~m}$ and $154 \times 10^{-3} \mathrm{~m}$. The interface element consisted of pairs of nodes compatible with a sixnode triangular side of a soil element or a plate element [11].

3.5. Water Head Variations. Water pressure has a direct effect on strength of soils, on pressure against the wall, and on uplift of soil in the bottom of the excavation. Many situations are not hydrostatic before the work starts but change during the work. These conditions can be modelled in FEA [16]. For the variation in water head, the piezometer readings obtained for different months and presented in Table 4 were used separately for the water table height to obtain the maximum soil stress on the protection shield wall. 


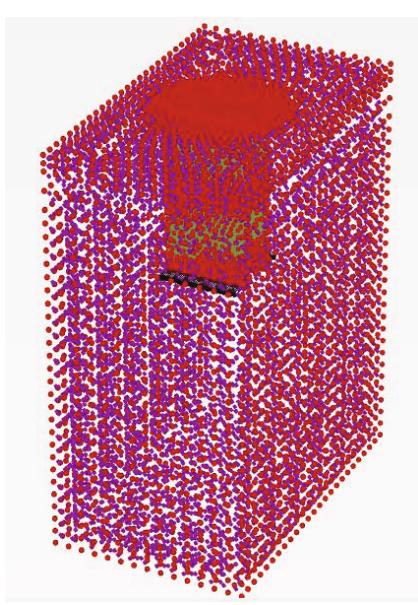

(a) Soil mesh

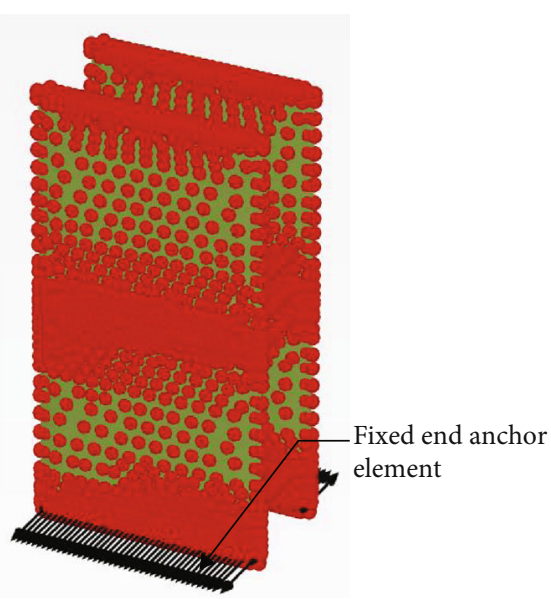

(b) Structural mesh

FIgURE 8: Mesh generation of the soil and structural elements in PLAXIS-3D.

TABLE 5: Construction sequence of FE modelling in PLAXIS-3D.

\begin{tabular}{lcc}
\hline Phase & In the model & Drainage \\
\hline Phase 0 & Only soil elements $($ no structure) & $K_{0}$ procedure \\
Phase 1 & Excavation $\left(1^{\text {st }}\right.$ layer, depth: $\left.0.6 \mathrm{~m}\right)$ fissured brown clay & Drained \\
Phase 2 & Excavation $\left(2^{\text {nd }}\right.$ layer: 0.6 to $\left.2 \mathrm{~m}\right)$ brow clay & Plastic: undrained $B$ (soil model) \\
Phase 3 & Adding structural element & Plastic: undrained $B$ (soil model) \\
Phase 4 & Excavation $\left(3^{\text {rd }}\right.$ layer: $2 \mathrm{~m}$ to $\left.6 \mathrm{~m}\right)$ sensitive blue clay & Plastic: undrained $B$ (soil model) \\
\hline
\end{tabular}

Note: the definition of undrained $B$ is discussed in construction step 2: phase 2.

3.6. Mesh Generation. A medium-coarse 10-node element was used for each of the simulation and connectivity plot elements shown in Figure 8. This mesh generation process considers the soil, all the structural components, loads, and boundary conditions. As a result of meshing, a total number of elements of 24,271 , i.e., 23,221 soil elements and 1,050 structural elements, was reached.

\section{Construction Steps and Phases in PLAXIS- 3D Simulation}

Poulos et al. [18] showed that construction details and sequence, as well as soil-structure interaction, have a significant impact on the movements and lateral loads acting on a flexible retaining structure. Therefore, the construction steps constituted a major and critical part of this FE simulation. The model assigned a step-by-step excavation sequence including the structural elements inserted into the excavation. All the phases of the construction sequence are summarized in Table 5.

4.1. Construction Step 0: Initial Phase. In the initial phase, only the natural (undisturbed) soil was considered. No excavation was made in this step, and only $K_{0}$ (the parameter to produce initial stress) was considered in the calculations. In general, $K_{0}$ values can be specified, $K_{0, x}=\sigma_{x x}^{\prime} / \sigma_{z z}^{\prime}$ in the $x$ -direction and $K_{0, y}=\sigma_{y y}^{\prime} / \sigma_{z z}^{\prime}$ in the $y$-direction. The default
$K_{0}$ values are defined by the Jaky [19] coefficient as follows:

$$
K_{0}=1-\sin \varphi,
$$

where $\varphi$ is the frictional angle. A staged construction loading type was selected to generate the initial stresses. The initial stresses in a soil body are influenced by the weight of the soil, the water conditions, and the history of its formation. This stress state can be generated using either the $K_{0}$ procedure or gravity loading. The $K_{0}$ procedure should preferably be used in cases with a horizontal surface and with all soil and phreatic levels parallel to the surface [11], as in the case under consideration.

4.2. Construction Step 1: Phase 1. In construction step 1, the first layer $(0 \mathrm{~m}-0.6 \mathrm{~m}$ depth) of fissured brown clay was excavated, representing an excavation contour of [ $3 \mathrm{~m}(10$ $\mathrm{ft}) \times 1.5 \mathrm{~m}(5 \mathrm{ft}) \times 0.6 \mathrm{~m}(2 \mathrm{ft})]$. For this phase, the plastic calculation and the "drained" soil drainage type were selected, as shown in Figure 9(b). Therefore, the soil will behave as in a drained condition, unlike the clay below, which will behave as an undrained medium for shortterm analyses.

4.3. Construction Step 2: Phase 2. In construction step 2, the second layer $(0.6 \mathrm{~m}-2 \mathrm{~m}$ depth) of plastic brown clay was excavated, representing an excavation contour of $[3 \mathrm{~m}(10 \mathrm{ft}$ )$\times 1.5 \mathrm{~m}(5 \mathrm{ft}) \times 2 \mathrm{~m}(6.56 \mathrm{ft})]$, as shown in Figure 9(c). The 


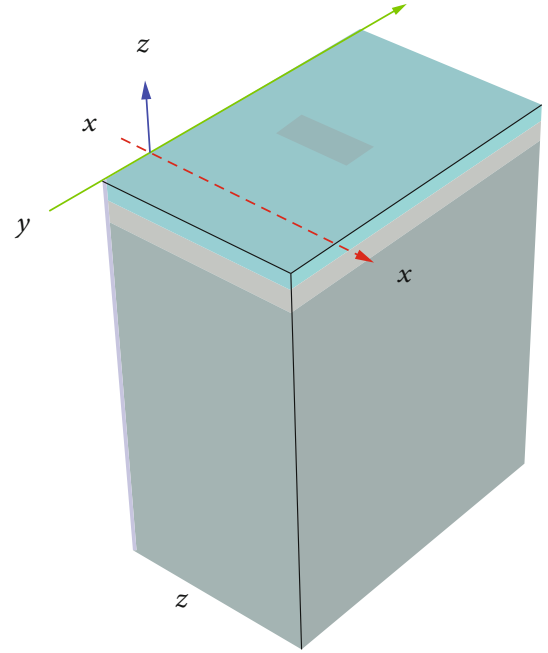

(a) Step 0 (initial phase)

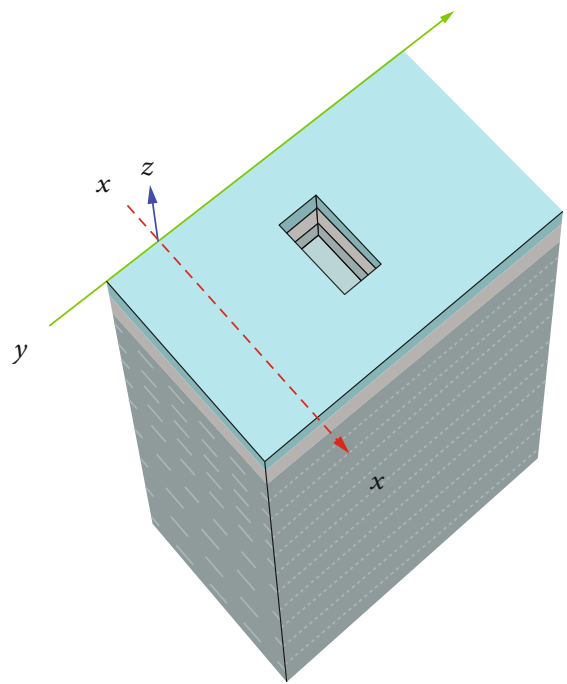

(c) Step 2 (phase 2)

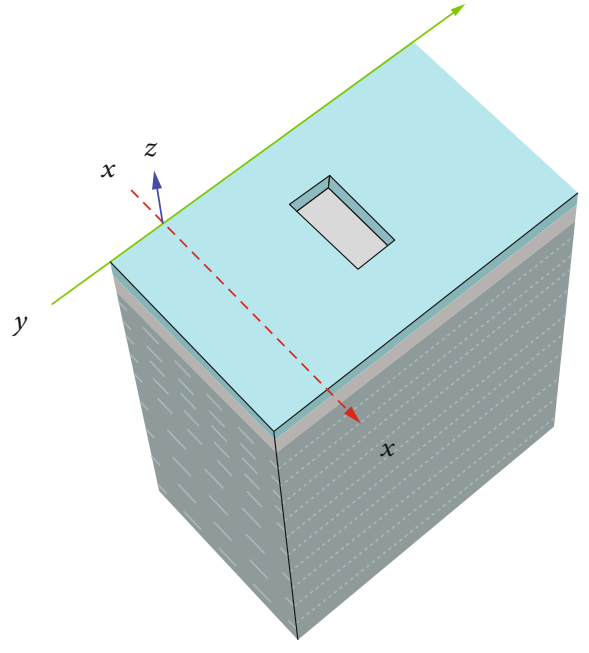

(b) Step 1 (phase 1)

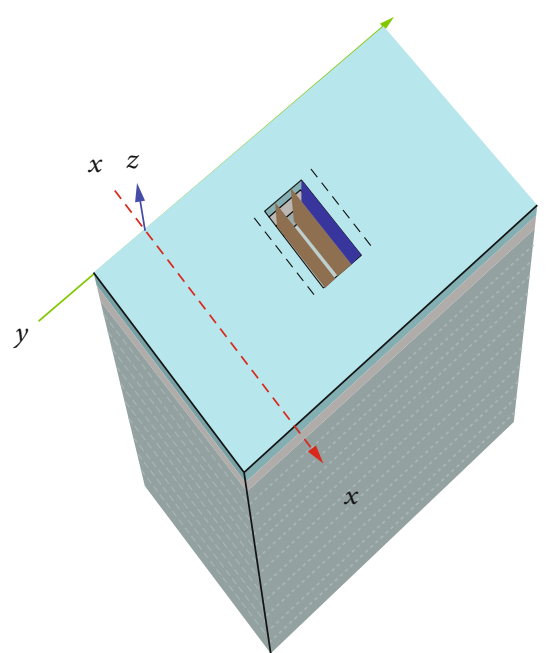

(d) Step3 (phase 3)

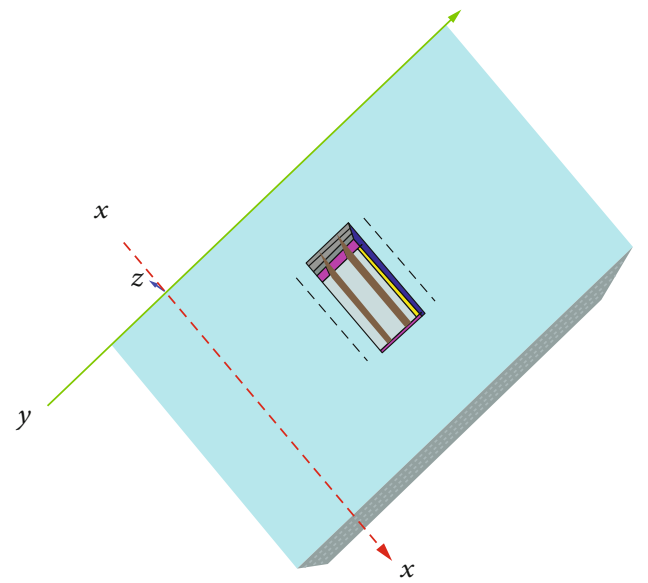

(e) Step 4 (phase 4)

Figure 9: PLAXIS-3D simulation for the construction steps.

undrained $B$ soil drainage type and the plastic calculation were assumed for this layer. In this undrained condition, assuming that no water was moving, long- and shortterm loading behavior was assessed [11], including built- up excess pore pressures. In the undrained $(B)$ drainage type, modelling of undrained behavior using effective parameters for stiffness and undrained shear-strength parameters was allowed. 


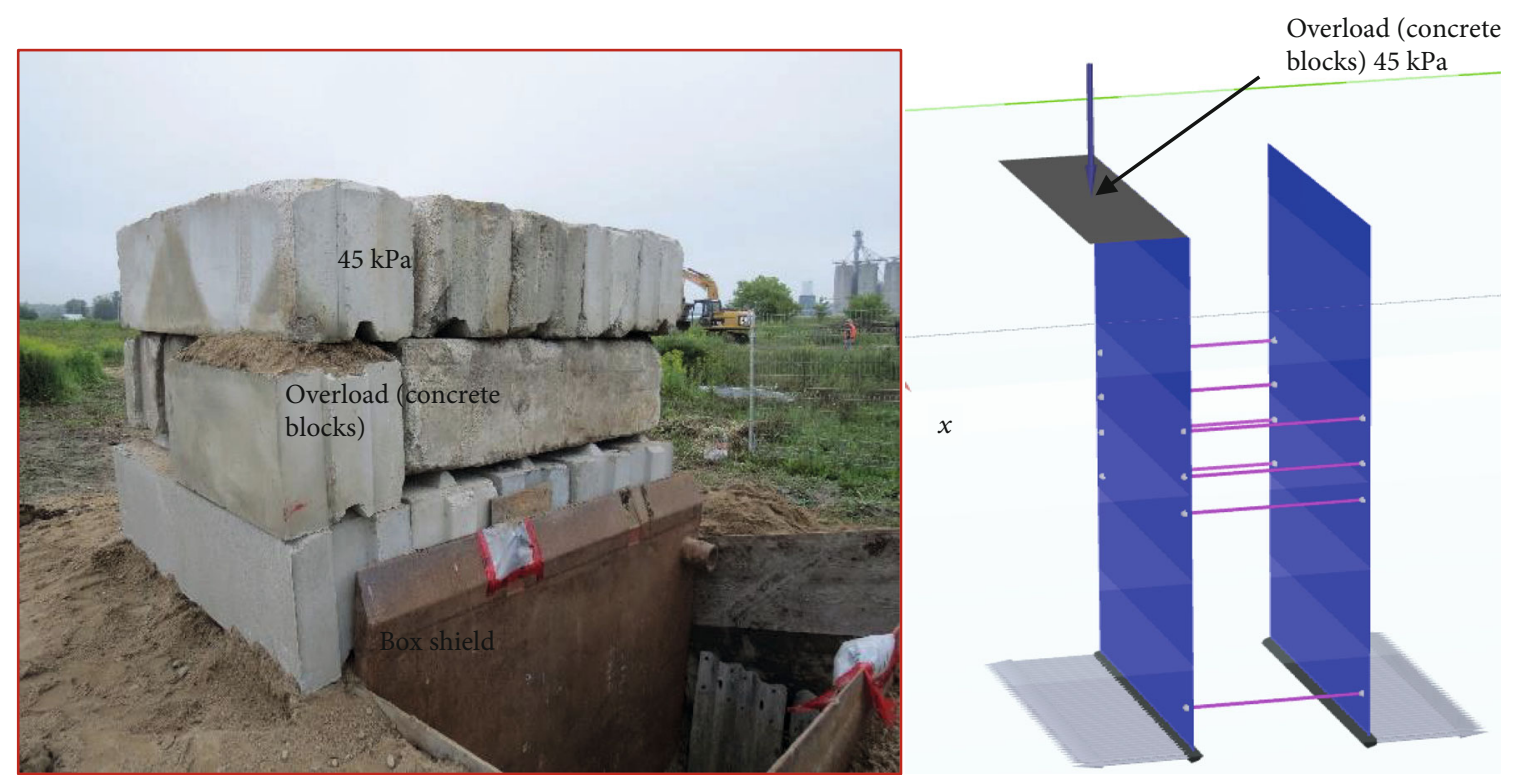

FIGURE 10: PLAXIS-3D simulation for the construction step 4 (phase 4) with overloading as per experimental site.

TABLE 6: Soil pressure for different depths of excavation by the PLAXIS-3D MC model without MRF (option $B$ ) compared with experimental.

\begin{tabular}{lcccc}
\hline $\begin{array}{l}\text { Depth from top } \\
(\mathrm{m})\end{array}$ & $\begin{array}{c}\text { MC model without } \\
\text { overloading }(\mathrm{kPa})\end{array}$ & $\begin{array}{c}\text { MC method with } \\
\text { overloading }(\mathrm{kPa})\end{array}$ & $\begin{array}{c}\text { Experimental without } \\
\text { overloading }(\mathrm{kPa})\end{array}$ & $\begin{array}{c}\text { Experimental with } \\
\text { overloading }(\mathrm{kPa})\end{array}$ \\
\hline 0 & 0 & 0 & 0 & 0 \\
0.9 & 3 & 10 & 5 & 6 \\
2.4 & 39 & 41 & 15 & 23 \\
3.9 & 51 & 52 & 114 & 714 \\
5.4 & 79 & 79 & 77 & 77 \\
\hline
\end{tabular}

4.4. Construction Step 3: Phase 3. In this step, a structure consisting of two box-shield excavation protectors "stacked upon each other" $[3 \mathrm{~m}(10 \mathrm{ft}) \times 1.5 \mathrm{~m}(5 \mathrm{ft}) \times 6 \mathrm{~m}(20 \mathrm{ft})]$ (Figure 4) was inserted into the simulated excavation, as shown in Figure $9(\mathrm{~d})$. The undrained $B$ soil drainage type and the plastic calculation were assumed for this phase.

4.5. Construction Step 4: Phase 4. In this construction step, $2 \mathrm{~m}$ to $6 \mathrm{~m}$ of sensitive blue clay soil was excavated, as shown in Figure 9(e). In addition, a $45 \mathrm{kPa}(0.94 \mathrm{ksf})$ surface overload was applied on one side of the excavation in the PLAXIS-3D model to create an extreme load case, as shown in Figure 10. The undrained $B$ soil drainage type and the plastic calculation were also selected for this phase.

\section{Analysis Using Mohr-Coulomb (MC) Models and Results}

The MC model represents a "first-order" approximation of soil and rock behavior [11]. For that reason, the MC constitutive model with soil parameters given in Table 2 was considered as a first simulation analysis. The obtained soil stresses are presented in Table 6 for different depths with and without overloading. These depths are representative of the experimental location of the pressure cells because the objective was to find the soil stress in the PLAXIS-3D simulation at the same locations as in the experimental setup. In Table 6, it is very clear that the effect of an overload applied close to the trench was more pronounced on the upper part of the protective shield than on the deeper part [20]. It follows that the pressures on the plate at $0.9 \mathrm{~m}$ and $2.4 \mathrm{~m}$ depths of the trench were more influenced by the $45 \mathrm{kPa}(0.94 \mathrm{ksf})$ overload both in the MC simulation and in the experimental results. In contrast, it had a negligible effect on the deeper part of the plate.

5.1. MC Model with Modulus Reduction Factor (MRF). Soft to medium clays may exhibit strength anisotropy, or in other words, their strength varies with the orientation of the failure surface [16]. Therefore, the results from the MC model must be verified using another approach. Relative shear stresses were considered, which yield an indication of the stress point to the failure envelope. The relative shear stresses (relative shear stress $\tau_{\text {rel }}=\left[\right.$ mobilized shear stress $\left(\tau_{\text {mob }}\right) /$ maximum shear stress $\left.\left.\left(\tau_{\max }\right)\right]\right)$ at the end of phases 2 and 4 of the PLAXIS-3D MC model output are shown in Table 7. Based on the maximum value of relative shear stress, the mobilized shear strength $\left(\tau_{\mathrm{mob}}\right)$ was then adopted from the modulus reduction vs. mobilized strength curve of undrained Thanet 
TABLE 7: Calculation of modulus reduction factor and corresponding elastic modulus $(E)$ and shear modulus $(G)$.

\begin{tabular}{|c|c|c|c|c|c|}
\hline \multirow[t]{2}{*}{ Depth } & \multicolumn{2}{|c|}{$\begin{array}{l}\text { Relative shear } \\
\text { stress from } \\
\text { PLAXIS-3D } \\
\text { results }\end{array}$} & \multirow{2}{*}{$\begin{array}{l}\text { Value of modulus } \\
\text { reduction }\left(E / E_{\max } \text { or } G /\right. \\
\left.G_{\max }\right) \text { factor } \\
\text { From Mayne [21] curve } \\
\text { (Thanet undrained clay) }\end{array}$} & \multirow[t]{2}{*}{$\begin{array}{c}E \\
(\mathrm{kPa})\end{array}$} & \multirow[t]{2}{*}{$\begin{array}{c}G \\
(\mathrm{kPa})\end{array}$} \\
\hline & $\begin{array}{c}\text { Phase } \\
2\end{array}$ & $\begin{array}{c}\text { Phase } \\
4\end{array}$ & & & \\
\hline 0 & 0 & 0 & 0 & 0 & 0 \\
\hline 0.6 & 0.4 & 0.4 & 0.205 & 5,125 & 3,280 \\
\hline 1 & 0.6 & 0.6 & 0.11 & 3,740 & 1,980 \\
\hline 2 & 0.53 & 0.55 & 0.12 & 2,720 & 1,800 \\
\hline 3 & 0.754 & 0.885 & 0.1 & 2,750 & 1,600 \\
\hline 4 & 0.684 & 0.969 & 0.08 & 2,413 & 1,320 \\
\hline 5 & 0.694 & 0.734 & 0.105 & 3,465 & 2,205 \\
\hline 6 & 0.635 & 0.968 & 0.65 & 2,773 & 1,440 \\
\hline 7 & 0.712 & 0.959 & 0.08 & 2,800 & 1,440 \\
\hline 8 & 0.1 & 0.1 & 0.65 & 25,783 & 14,950 \\
\hline 9 & 0.04 & 0.053 & 0.75 & 31,500 & 19,500 \\
\hline 10 & 0.05 & 0.067 & 0.78 & 33,540 & 21,060 \\
\hline 11 & 0.02 & 0.02 & 0.9 & 34,400 & 21,600 \\
\hline 12 & 0.011 & 0.011 & 0.9 & 40,800 & 24,300 \\
\hline 13 & 0.01 & 0.01 & 0.9 & 43,200 & 24,300 \\
\hline 14 & 0.004 & 0.004 & 0.105 & 39,600 & 24,300 \\
\hline
\end{tabular}

clay soil [21] to estimate the modulus reduction factor (MRF). The MRF is the ratio of elastic modulus $\left(E / E_{\max }\right)$ or shear modulus $\left(G / G_{\max }\right)$. Thanet clay was considered because it is a soft undrained clay, much like the Louiseville clay. New $E$ and $G$ values were computed from the Kramer [22] equations (3) and (4) with the corresponding MRF values of the Mayne [21] curve for each soil layer up to $14 \mathrm{~m}$ depth, as shown in Table 7:

$$
\begin{gathered}
E=\mathrm{S}_{u}(\text { at Louiseville }) * \mathrm{MRF} * 1,000, \\
G=G(\text { at Louiseville }) * \mathrm{MRF} * 1,000 .
\end{gathered}
$$

Then, these values were used as a PLAXIS-3D input to run the model again and obtain the maximum soil pressures MC with MRF (with $E$ (option $C_{1}$ ) and with $\mathrm{G}$ (option $C_{2}$ )).

5.2. Mohr-Coulomb Reduction Factor with Shear Strain. In this method, the shear strains from the PLAXIS-3D output results of the MC model for each depth shown in Table 8 were assumed. The Vucetic and Dobry [23] curve $\left(G / G_{\max }\right.$ vs. cyclic shear strain $(\gamma)$ ) was used to find the corresponding modulus reduction factor $\left(G / G_{\max }\right)$. Note that the PI $=50$ curve was used because the plasticity index (PI) of the Louiseville soil is 42 [24]. With the value of the modulus reduction factor, Equation (5) was used to calculate the shear modulus for Louiseville clay:

$$
G=\operatorname{MRF} * G_{\max } \cdot
$$

TABLE 8: Calculation of modulus reduction factor and

\begin{tabular}{|c|c|c|c|c|}
\hline $\begin{array}{l}\text { Depth } \\
(\mathrm{m})\end{array}$ & $\begin{array}{l}\text { Shear strain, } \gamma(\mathrm{m} / \mathrm{m}) \\
\qquad\left(10^{-3}\right)\end{array}$ & $\begin{array}{c}\text { Modulus } \\
\text { factor } \\
\left(G / G_{\max }\right) \\
\text { value from } \\
\text { Vucetic and } \\
\text { Dobry [23] } \\
\text { curve (for PI } \\
=50)\end{array}$ & $\begin{array}{c}G \\
(\mathrm{kPa})\end{array}$ & $E(\mathrm{kPa})$ \\
\hline 0 & 0 & 0 & 0 & 0 \\
\hline 0.6 & 0.24 & 0.7 & 11,200 & $2.91 \times 10^{4}$ \\
\hline 1 & 0.351 & 0.6 & 10,800 & $2.81 \times 10^{4}$ \\
\hline 2 & 0.745 & 0.46 & 6,900 & $1.79 \times 10^{4}$ \\
\hline 3 & 0.486 & 0.5 & 8,000 & $2.08 \times 10^{4}$ \\
\hline 4 & 1.415 & 0.12 & 1,980 & $5.148 \times 10^{3}$ \\
\hline 5 & 0.79 & 0.43 & 9,030 & $2.35 \times 10^{4}$ \\
\hline 6 & 1.247 & 0.14 & 2,520 & $6.552 \times 10^{3}$ \\
\hline 7 & 0.814 & 0.36 & 6,480 & $1.69 \times 10^{4}$ \\
\hline 8 & 0.053 & 0.83 & 19,090 & $4.96 \times 10^{4}$ \\
\hline 9 & 0.035 & 0.85 & 22,100 & $5.75 \times 10^{4}$ \\
\hline 10 & 0.028 & 0.86 & 23,220 & $6.04 \times 10^{4}$ \\
\hline 11 & 0.025 & 0.87 & 23,490 & $6.11 \times 10^{4}$ \\
\hline 12 & 0.016 & 0.88 & 23,760 & $6.18 \times 10^{4}$ \\
\hline 13 & 0.012 & 0.9 & 24,300 & $6.32 \times 10^{4}$ \\
\hline 14 & 0.007 & 0.98 & 26,460 & $6.88 \times 10^{4}$ \\
\hline
\end{tabular}
corresponding elastic modulus $(E)$ and shear modulus $(G)$ from shear strain.

Then, these values were input to the analysis to obtain the maximum soil pressures MC with MRF (for IP $=50$ (option $\left.C_{3}\right)$ ).

5.3. Validation of the MC Model. To validate the MC model, parameters such as $K_{0}$ and the pore pressure must be checked. In practice, $K_{0}$ for a normally consolidated soil is often assumed to be related to the friction angle by Jaky's empirical expression (Equation (2)). In an overconsolidated soil, $K_{0}$ would be expected to be larger than the value given by this expression. However, for the Mohr-Coulomb model, the default $K_{0}$ value is based on Jaky's formula. Hamouche et al. [25] evaluated the in situ coefficient of earth pressure at rest for Louiseville sensitive clay. Three values of $K_{0}$ $(0.55,1$, and 1.5$)$ from the profile were chosen to validate the MC model to take account of fluctuations in soil pressure with depth: (i) $K_{0}=0.55$ is the value computed from Jaky's formula with $\phi=27^{\circ}$, which is a common friction angle for clays or gravity loading; (ii) $K_{0}=1$ represents the case for clay in undrained conditions only (when $\phi=0$ ); and (iii) $K_{0}=1.5$ represents the experimental profile at $6 \mathrm{~m}$ depth. Table 9 and Figure 11 show the soil pressures with different $K_{0}$ values after analysis using the M-C model. 
TABLE 9: Soil pressure at different depths of the excavation by the PLAXIS-3D MC model with different $K_{0}$.

\begin{tabular}{lccc}
\hline \multirow{2}{*}{ Depth from top $(\mathrm{m})$} & \multicolumn{3}{c}{ Soil pressure $(\mathrm{kPa})$} \\
& $K_{0}=0.55$ gravity loading & $K_{0}=1$ & $K_{0}=1.5$ \\
\hline 0 & 0 & 0 & 0 \\
0.9 & 1.5 & 10 & 13 \\
2.4 & 26 & 39 & 55 \\
3.9 & 44 & 52 & 66 \\
5.4 & 60 & 79 & 98 \\
\hline
\end{tabular}

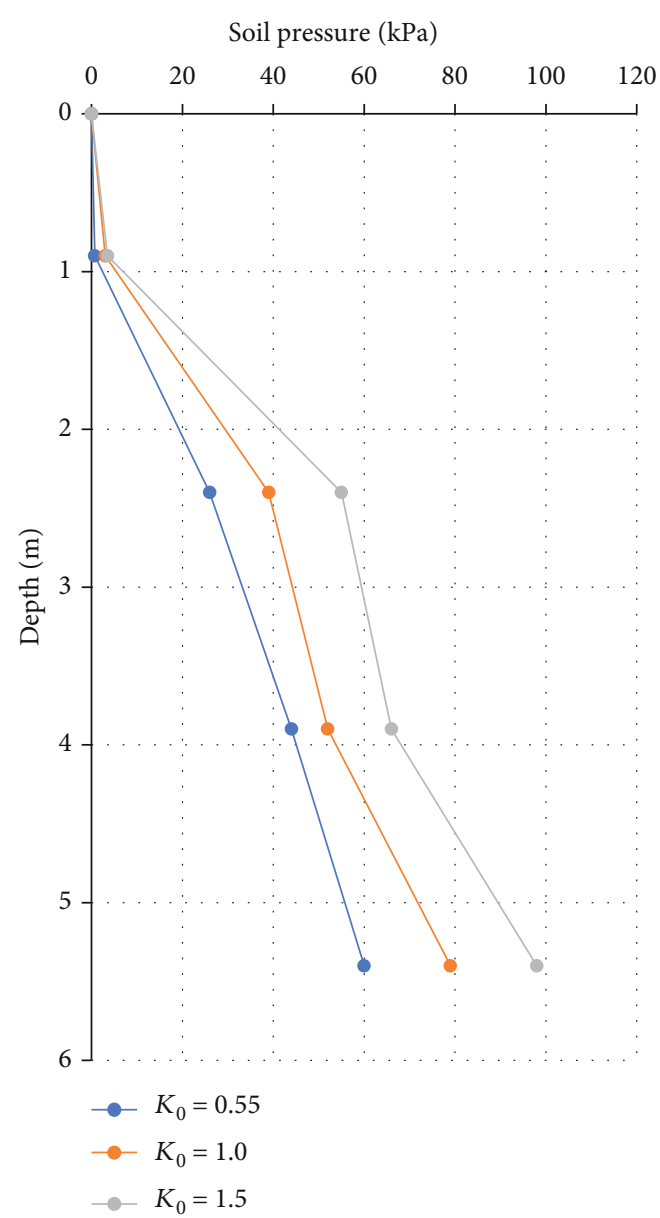

Figure 11: Soil pressure at different depth of trench with different $K_{0}$ values.

\section{Simulation Analysis Using the Hardening Soil (HS) Material Model}

Using the same structural properties and soil layers, the HS model [26] was used to predict the constitutive behavior of the soils. Table 10 presents the soil properties used for HS simulation. Allen Marr and Hawkes [16] stated that for soft clay, the $E_{50}$ modulus varies between $2,500 \mathrm{kPa}(52 \mathrm{ksf})$ and $15,000 \mathrm{kPa}(313 \mathrm{ksf})$. For Chicago soft and undrained clay, $E_{50}$ was reported to be $2,350 \mathrm{kPa}$ (49 ksf) [9]. Considering that Louiseville soft and sensitive clay is softer than Chicago clay, its $E_{50}$ modulus was therefore assumed equal to
$2,000 \mathrm{kPa}(42 \mathrm{ksf})$. For the undrained $B$ in the HS model, the stiffness moduli in the model are no longer stress-dependent, and the model exhibits no compression hardening. Again, the undrained shear strength $\left(S_{u}\right)$ for the Louiseville soil was an input parameter to the HS model. Soil pressures from the HS model (option $A$ ) along the trench depth are presented in Table 11.

\section{Overall Results and Comparisons}

The FEA results were compared to available theoretical predictions and results from the Louiseville experimental in situ test. Apparent earth pressure according to the Terzaghi and Peck [27] methods (TPM) and active earth pressure as developed by Rankine [28] and Yokel et al. [6] were also used to calculate theoretical soil pressures for Louiseville soft and sensitive clay. The results are summarized in Table 11 and Figure 12. Note that the experimental values are based on experimental field results for the period from 14 May to 10 August 2018. From Table 11 and Figure 12, the following comparative observations can be made:

(1) MC versus theoretical predictions: MC model (B) (without MRF) yielded values closer to Rankine's [28] analytical results. MC models with MRF (options $\left[C_{1}\right],\left[C_{2}\right]$, and $\left[C_{3}\right]$ ) gave closer results to the TPM (1967) at $2.4 \mathrm{~m}$ depth and higher values than TPM at higher depths. TPM does not predict the same pattern of soil pressure at greater depths in the trench compared to the other analytical methods and the MC model. The various MRF methods explored in the present study (options $\left[C_{1}\right]$ , $\left[C_{2}\right]$, and $\left[C_{3}\right]$ ) produced similar results (with the exception of option $\left[C_{3}\right]$ at $3.9 \mathrm{~m}$ depth), and the overall results were comparable to those from option $[B]$ (without MRF)

(2) MC versus experimental values: the experimental results showed closer values to the $\mathrm{MC}$ (option $\left[\mathrm{C}_{3}\right]$ ) model results at $0.9 \mathrm{~m}(3 \mathrm{ft})$ from the top of the trench. All of the MC models produced soil pressure values lower than the experimental measurement at $3.9 \mathrm{~m}$ depth $(12.8 \mathrm{ft})$. At $5.4 \mathrm{~m}$ depth, MC without MRF (option $[B]$ ) produced the closest value to the experimental soil pressure. MC method is a simple and practical option when in situ shear-strength values are known to engineers. However, no MC model (with or without MRF) stood out and yielded results closer to those measured during the field tests

(3) HS versus theoretical predictions: HS (option A) model results were closer to the Yokel et al. [6] analytical value at $2.4 \mathrm{~m}$ from the top of the trench. Results also show that the Yokel method overestimated earth pressure in the upper part of the trench, compared to the HS method that overestimated earth pressure in the deeper part of the trench

(4) HS versus experimental values: HS (option $A$ ) at $3.9 \mathrm{~m}$ trench depth yielded a pressure closer to the 
TABle 10: Properties of Louiseville soil and hardening soil (HS) material model parameters used for FE modelling.

\begin{tabular}{|c|c|c|c|c|}
\hline Parameter/properties & $\begin{array}{l}\text { PLAXIS-3D nomenclature } \\
\text { (unit) }\end{array}$ & $\begin{array}{l}\text { Fissured brown } \\
\text { clay }\end{array}$ & $\begin{array}{l}\text { Plastic brown } \\
\text { clay }\end{array}$ & $\begin{array}{l}\text { Sensitive blue } \\
\text { clay }\end{array}$ \\
\hline Depth of layer & $\mathrm{m}$ & $0.0-0.6$ & $0.6-2$ & $2-15$ \\
\hline Material model & Model & HS & HS & HS \\
\hline Drainage type & Type & Undrained B & Undrained B & Undrained B \\
\hline Unit wt. above phreatic level & $\gamma_{\text {unsat }}\left(\mathrm{kN} / \mathrm{m}^{3}\right)$ & 16 & 16 & 16 \\
\hline Unit wt. below phreatic level & $\gamma_{\text {sat }}\left(\mathrm{kN} / \mathrm{m}^{3}\right)$ & 17 & 17 & 17 \\
\hline Secant stiffness for CD triaxial test & $E_{50 \text { ref }}\left(\mathrm{kN} / \mathrm{m}^{2}\right)$ & $2 \times 10^{3}$ & $2 \times 10^{3}$ & $2 \times 10^{3}$ \\
\hline Tangent oedometer stiffness & $E_{\text {oed ref }}\left(\mathrm{kN} / \mathrm{m}^{2}\right)$ & $2 \times 10^{3}$ & $2 \times 10^{3}$ & $2 \times 10^{3}$ \\
\hline Unloading/reloading stiffness & $E_{\text {ur ref }}\left(\mathrm{kN} / \mathrm{m}^{2}\right)$ & $1 \times 10^{4}$ & $1 \times 10^{4}$ & $1 \times 10^{4}$ \\
\hline Power for stress level dependency of stiffness & $\mathrm{m}$ & 1 & 1 & 1 \\
\hline Shear strength of soil & $S_{u}(\mathrm{kPa})$ & 29 & 29 & 38 \\
\hline Cohesion & $C_{\mathrm{ref}}^{\prime}\left(\mathrm{kN} / \mathrm{m}^{2}\right)$ & 5 & 5 & 5 \\
\hline Frictional angle & $\varnothing\left({ }^{\circ}(\right.$ degree $\left.)\right)$ & 28 & 28 & 28 \\
\hline Dilatancy angle & $\Psi\left({ }^{\circ}(\right.$ degree $\left.)\right)$ & 0 & 0 & 0 \\
\hline Poisson's ratio & $v_{\mathrm{ur}}^{\prime}$ & 0.3 & 0.3 & 0.3 \\
\hline Interface reduction factor & $R_{\text {inter }}$ & 0.65 & 0.5 & 0.5 \\
\hline Initial $K_{0}$ determination & $K_{0}$ & 0.53 & 0.53 & 0.53 \\
\hline Overconsolidation ratio & OCR & 1.5 & 1.5 & 3 \\
\hline Preoverburden pressure & $\mathrm{POP}\left(\mathrm{kN} / \mathrm{m}^{2}\right)$ & 0 & 0 & 0 \\
\hline Soil type & & & & Very fine \\
\hline$<2 \mathrm{~m} \mu$ & $\%$ & 10 & 10 & 74 \\
\hline $2 \mathrm{~m} \mu-50 \mathrm{~m} \mu$ & $\%$ & 13 & 13 & 11 \\
\hline
\end{tabular}

TABLE 11: Comparison of soil pressures on flexible temporary shield in soft and sensitive clay excavated trench.

\begin{tabular}{|c|c|c|c|c|c|c|c|c|c|}
\hline \multirow[b]{2}{*}{$\begin{array}{l}\text { Depth } \\
\text { from } \\
\text { top of } \\
\text { the soil } \\
\text { (m) }\end{array}$} & \multirow{2}{*}{$\begin{array}{l}\text { In situ test } \\
\text { results } \\
\text { Experimental- } \\
\text { option }(\mathrm{kPa})\end{array}$} & \multicolumn{5}{|c|}{$\begin{array}{l}\text { Finite element model analysis results using } \\
\text { PLAXIS-3D }\end{array}$} & \multicolumn{3}{|c|}{ Analytical results } \\
\hline & & $\begin{array}{l}\text { HS- } \\
\text { model } \\
{[A]} \\
(\mathrm{kPa})\end{array}$ & $\begin{array}{c}\text { MC } \\
\text { without } \\
\text { MRF }[B] \\
(\mathrm{kPa})\end{array}$ & $\begin{array}{c}\text { MC } \\
\text { with } \\
\text { MRF } \\
\text { (with } E \text { ) } \\
{\left[C_{1}\right]} \\
(\mathrm{kPa})\end{array}$ & $\begin{array}{c}\text { MC } \\
\text { with } \\
\text { MRF } \\
(\text { with } G) \\
{\left[C_{2}\right]} \\
(\mathrm{kPa}) \\
\end{array}$ & $\begin{array}{c}\text { MC with } \\
\text { MRF (for } \\
\mathrm{IP}=50) \\
{\left[C_{3}\right]} \\
(\mathrm{kPa})\end{array}$ & $\begin{array}{l}\text { Calculated stress } \\
\text { from Terzaghi } \\
\text { and Peck [27]: } \\
\begin{array}{c}P_{A}= \\
1.0 K_{A} \cdot \gamma \cdot H \\
(\mathrm{kPa})\end{array}\end{array}$ & $\begin{array}{l}\text { Calculated total active } \\
\text { stress from Rankine } \\
{[28]: P=0.5} \\
\left(\gamma \cdot H^{2}-4 S_{u} H\right)(\mathrm{kPa})\end{array}$ & $\begin{array}{c}\text { Calculated stress } \\
\text { from Yokel et al. } \\
{[6]: P=\mathrm{We}} \\
(H+0.6)(\mathrm{kPa})\end{array}$ \\
\hline 0 & 0 & 0 & 0 & 0 & 0 & 0 & 0 & 0 & 75.69 (1.58 ksf) \\
\hline $\begin{array}{l}0.9 \\
(2.95 \mathrm{ft})\end{array}$ & 6 (0.125 ksf) & $\begin{array}{c}11 \\
(0.23 \mathrm{ksf} \\
)\end{array}$ & $\begin{array}{c}10 \\
(0.2 \mathrm{ksf})\end{array}$ & $\begin{array}{c}1 \\
(0.02 \mathrm{ksf} \\
)\end{array}$ & $\begin{array}{c}3 \\
(0.06 \mathrm{ksf} \\
)\end{array}$ & $\begin{array}{c}4 \\
(0.08 \mathrm{ksf})\end{array}$ & 44 (0.92 ksf) & 12.69 (0.265 ksf) & 75.69 (1.58 ksf) \\
\hline $\begin{array}{l}2.4 \\
(7.9 \mathrm{ft})\end{array}$ & 23 (0.48 ksf) & $\begin{array}{c}71 \\
(1.48 \mathrm{ksf} \\
)\end{array}$ & $\begin{array}{c}39 \\
(0.81 \mathrm{ksf} \\
)\end{array}$ & $\begin{array}{c}43 \\
(0.9 \mathrm{ksf})\end{array}$ & $\begin{array}{c}42 \\
(0.88 \mathrm{ksf} \\
\quad)\end{array}$ & $38(0.79)$ & 44 (0.92 ksf) & 33.84 (0.71 ksf) & 75.69 (1.58 ksf) \\
\hline $\begin{array}{l}3.9 \\
(12.8 \mathrm{ft})\end{array}$ & $114(2.38 \mathrm{ksf})$ & $\begin{array}{c}105 \\
(2.19 \mathrm{ksf} \\
)\end{array}$ & $\begin{array}{c}52 \\
(1.08 \mathrm{ksf} \\
)\end{array}$ & $\begin{array}{c}63 \\
(1.31 \mathrm{ksf} \\
)\end{array}$ & $\begin{array}{c}62 \\
(1.29 \mathrm{ksf} \\
)\end{array}$ & $\begin{array}{c}51 \\
(1.06 \mathrm{ksf})\end{array}$ & 44 (0.92 ksf) & $56(1.17 \mathrm{ksf})$ & 75.69 (1.58 ksf) \\
\hline $\begin{array}{l}5.4 \\
(17.7 \mathrm{ft})\end{array}$ & 77 (1.61 ksf) & $\begin{array}{c}143 \\
(3.0 \mathrm{ksf})\end{array}$ & $\begin{array}{c}79 \\
(1.65 \mathrm{ksf} \\
)\end{array}$ & $\begin{array}{c}86 \\
(1.8 \mathrm{ksf})\end{array}$ & $\begin{array}{c}84 \\
(1.75 \mathrm{ksf} \\
\quad)\end{array}$ & $\begin{array}{c}87 \\
(1.81 \mathrm{ksf})\end{array}$ & 44 (0.92 ksf) & 76.14 (1.59 ksf) & 75.69 (1.58 ksf) \\
\hline
\end{tabular}

in situ experimental test value. The reason for this may be that the elastic modulus $\left(E_{50}\right)$ assumed in the HS model at $3.9 \mathrm{~m}$ depth was extremely close to the measured site value of $2,000 \mathrm{kPa}(42 \mathrm{ksf})$. This brings out that the HS model may be a good option to compare soil pressure with experimental values in a trench box shield when the in situ shear strength of the soil must be assumed 


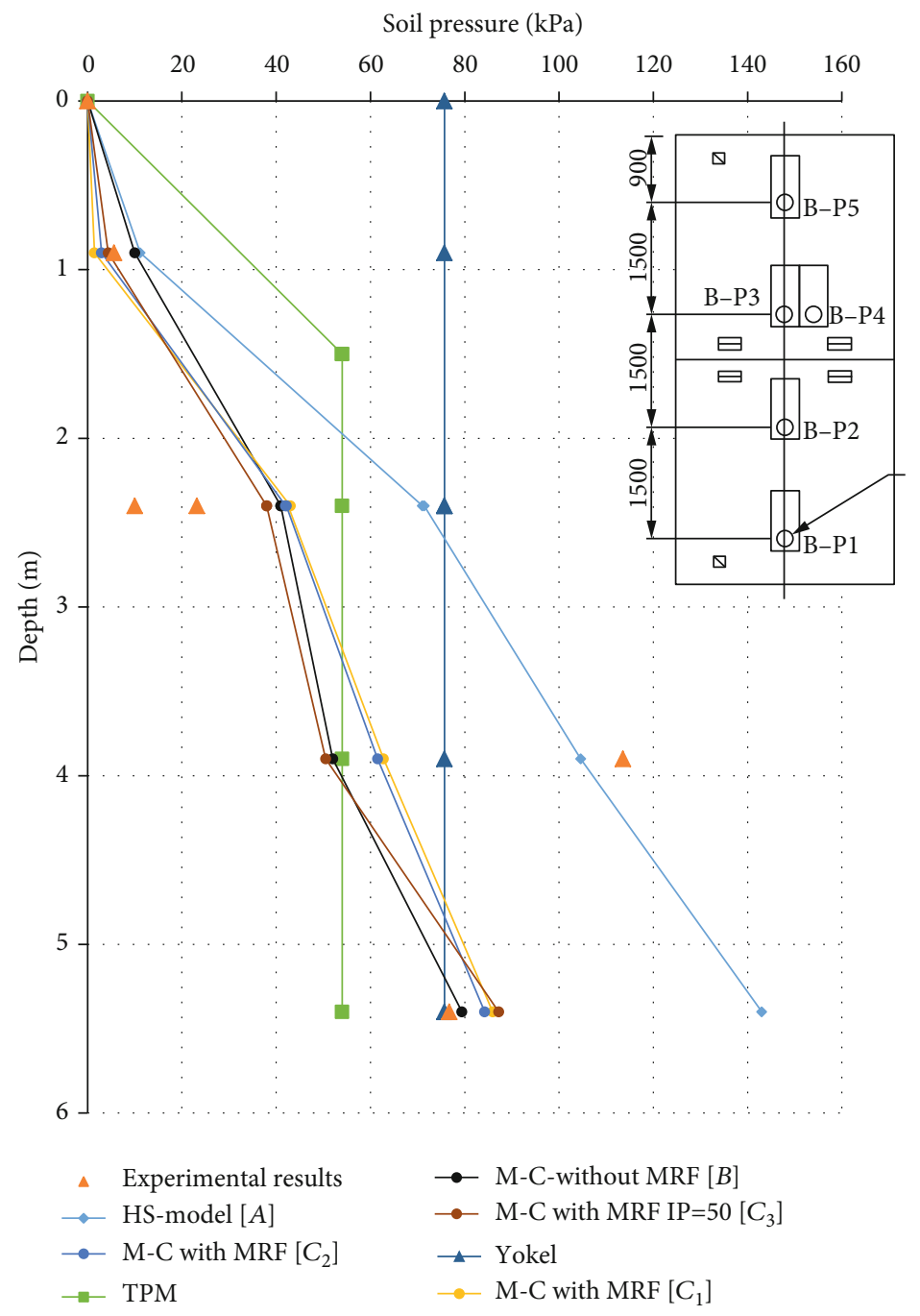

FIgURE 12: Maximum soil pressure vs. trench depth for different options of analysis.

The MC model offers some advantages because fewer input geotechnical parameters are required, yet the model yields acceptable results (compared to experimental values, except at $3.9 \mathrm{~m}$ depth) for the engineer when using common in situ geotechnical parameters such as shear strength. MRF methods explored in this study (options $\left[C_{1}\right],\left[C_{2}\right]$, and $\left.\left[C_{3}\right]\right)$ failed to offer more accurate results than the direct use of in situ shear strength parameters and Peck's formula (1975) to estimate the elastic properties of the MC model (option $[B]$ ). Clearly, precise modelling of the sensitive clay excavation would require more advanced behavioral laws, such as HS, and the input parameters of those constitutive models should be finetuned and adjusted based on extensive experimental laboratory soil testing.

In this study, FE model results were compared with the in situ experimental earth pressure data for soft and sensitive clay only. Further work is needed to gather experimental soil pressure data in various types of soils and then compare it to FE simulations.

\section{Conclusions}

The FE simulations using the PLAXIS-3D software presented in this paper confirm the measurements of earth pressures on the steel cage-type temporary shield protection at shallow depth in a soft and sensitive clay trench. The study included simulation of two steel box shields stacked upon each other, using "hinge connections" to cover the total trench depth of

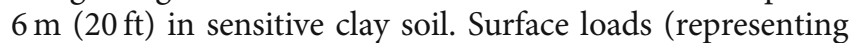
a $45 \mathrm{kPa}$ overload) located close to one side of the trench were simulated to produce a critical load case on the flexible wall of the shield. Two constitutive material models were used for the simulation analyses: (a) Mohr-Coulomb (MC) and (b) hardening soil (HS). Based on the FEA, the following conclusions can be drawn:

(i) Both HS and MC models revealed that the deeper part of the trench experienced higher pressures $(\mathrm{kPa})$ than the upper part. The maximum pressure reached $143 \mathrm{kPa}(3.0 \mathrm{ksf})$ and $87 \mathrm{kPa}(1.81 \mathrm{ksf})$ at 
$5.4 \mathrm{~m}$ from the top of the trench for the option $[A]$ and option $\left[C_{3}\right]$ models, respectively

(ii) Option $[A]$ of the HS model at $3.9 \mathrm{~m}$ trench depth yielded a pressure closer to the in situ experimental test value than options $[B],\left[C_{1}\right],\left[C_{2}\right]$, and $\left[C_{3}\right]$ of the $\mathrm{MC}$ model. This occurred because the elastic modulus $\left(E_{50}=2,000 \mathrm{kPa}\right)$ assumed in the HS model at that depth was extremely close to that on site

(iii) Options $\left[C_{1}\right],\left[C_{2}\right]$, and $\left[C_{3}\right]$ of the MC model with MRF results were comparable to those of option $[B$ ] of the MC model without MRF, showing thereby the key role played by the precise shear strength parameters

(iv) Comparisons of theoretical predictions by Rankine [28], Terzaghi and Peck [27], and Yokel et al. [6] for this type of soft and sensitive clay with FEA results revealed that the pressures obtained using Rankine and Yokel analytical formulae were closer to the simulated and experimental values than those of Terzaghi and Peck. Along the depth of the trench, the analytical formulae underestimated soil pressure around $4 \mathrm{~m}$ depth for this type of sensitive clay

\section{Data Availability}

The data that support the findings of this study are available from the corresponding author upon reasonable request.

\section{Conflicts of Interest}

The authors declare that they have no conflicts of interest.

\section{Acknowledgments}

The financial support of the Institut de Recherche RobertSauvé en Santé et en Sécurité du Travail (IRSST) through operating grants is gratefully acknowledged.

\section{References}

[1] K. Karlsrud and L. Andresen, "Loads on braced excavations in soft clay," International Journal of Geomechanics, ASCE, vol. 5, no. 2, pp. 107-113, 2005.

[2] OSHA, "Excavations: hazard recognition in trenching and shoring," in OSHA Technical Manual (OTM) (Vol. Section V), U.S. Department of Labor, Washington, DC, 2015.

[3] NBCC, National Building Code of Canada: Commentary K, National Research Council Canada, Ottawa, Ontario, Canada, 2015.

[4] CFEM, Canadian Foundation Engineering Manual, Canadian Geotechnical Society, Canada, 4th edition, 2006.

[5] Goldberg-Zoino \& Associates, Inc, Lateral Support Systems and Underpinning, Volume I. Design and Construction, Federal Highway Administration (FHWA), Washington D.C., 1976, https://rosap.ntl.bts.gov/view/dot/14528.

[6] F. Yokel, L. Tucker, and L. Reese, Soil Classification for Construction Practice in Shallow Trenching, National Bureau of Standards, Washington, DC, 1980.
[7] Y. Hashash and A. Whittle, "Ground movement prediction for deep excavations in soft clay," Journal of Geotechnical Engineering, ASCE, vol. 122, no. 6, pp. 474-486, 1996.

[8] S. Lam, "Ground movements due to excavation in clay: physical and analytical models," A dissertation submitted for the degree of doctor of philosophy, Churchill College, University of Cambridge, Cambridge, 2010.

[9] L. Bryson and D. Zapata-Medina, "Method for estimating system stiffness for excavation support walls," Journal of Geotechnical and Geoenvironmental Engineering, vol. 138, no. 9, pp. 1104-1115, 2012.

[10] M. Alam, O. Chaallal, and B. Galy, "Protection practices for trench and excavation in Quebec sensitive clay soils: review of codes, guidelines, and research needs," Safety Science, vol. 131, p. 104918, 2020.

[11] S. Bentley, Plaxis Material Models Manual, Bentley Systems, Exton, PA, 2017.

[12] R. Finno, J. Blackburn, and J. Roboski, "Three-dimensional effects for supported excavations in clay," Journal of Geotechnical and Geoenvironmental Engineering, vol. 133, no. 1, pp. 30-36, 2007.

[13] C. Ou, B. Shiau, and I. Wang, "Three-dimensional deformation behavior of the Taipei National Enterprise Center (TNEC) excavation case history," Canadian Geotechnical Journal, vol. 37, no. 2, pp. 438-448, 2000.

[14] M. Alam, "Evaluation of earth pressure and performance of shoring systems for Quebec sensitive clay: experimental and numerical study," A dissertation will be submit for the degree of Doctor of Philosophy, Department of Construction Engineering, Université de Québec, École de technologie supérieure, Montreal, 2020.

[15] P. Hsieh and C. Ou, "Shape of ground surface settlement profiles caused by excavation," Canadian Geotechnical Journal, vol. 35, no. 6, pp. 1004-1017, 1998.

[16] W. Allen Marr and M. Hawkes, "Displacement-based design for deep excavations," in Earth Retention Conference (ER) 2010 (pp. 82-100), Bellevue, Washington, 2010.

[17] R. Peck, The Selection of Soil Parameters for the Design of Foundations. Second Nabor Carrillo Lecture, Mexican Society for Soil Mechanics, Mexico, 1975.

[18] H. Poulos, J. Carter, and J. Small, "Foundations and earth retaining structures-research and practice," in 15th International Conference on Soil Mechanics and Geotechnical Engineering, Netherlands, 2002.

[19] J. Jaky, ""A nyugalmi nyomás tényezője" [the coefficient of earth pressure at rest]," Journal of the Society of Hungarian Architects and Engineers, vol. 78, no. 22, pp. 355-358, 1944.

[20] M. Boussinesq, Applications des Potentiels à l'Étude de l'Équilibre et Mouvement des Solides Élastiques, Gauthier-Villars, Imprimeur-Libraire, Paris, 1885.

[21] P. Mayne, "In-situ test calibrations for evaluating soil parameters," in Characterization and Engineering Properties of Natural Soils, T. Tan, K. Phoon, D. Hight, and S. Leroueil, Eds., vol. 3, pp. 1601-1652, CRC Press, Taylor \& Francis, London, 2006.

[22] S. Kramer, Geotechnical Earthquake Engineering, Pearson, 1996.

[23] M. Vucetic and R. Dobry, "Effect of soil plasticity on cyclic response," Journal of Geotechnical Engineering, vol. 117, no. 1, pp. 89-107, 1991.

[24] M. Roy, P. La Rochelle, and P. Leblond, "Geotechnical characterization and properties of a sensitive clay from Quebec," in 
Characterization and Engineering Properties of Natural Soils, T. Tan, K. Phoon, D. Hight, and S. Leroueil, Eds., vol. 1, pp. 363-394, CRC Press, Taylor \& Francis, London, 2002.

[25] K. Hamouche, S. Leroueil, M. Roy, and A. Lutenegger, "In situ evaluation of $\mathrm{K} 0$ in eastern Canada clays," Canadian Geotechnical Journal, vol. 32, no. 4, pp. 677-688, 1995.

[26] T. Schanz, P. Vermeer, and P. Bonnier, The Hardening Soil Model: Formulation and Verification, beyond 2000 in Computational Geotechnics - 10 Years of PLAXIS, Balkema, Rotterdam, Netherlands, 1999.

[27] K. Terzaghi and R. Peck, Soil Mechanics in Engineering Practice, Wiley, New York, 2nd edition, 1967.

[28] W. Rankine, On the Mathematical Theory of the Stability of Earth-Work and Masonry, The Royal Society of London, London, 1857. 